\title{
Terra Ignota. Marksizm kosmiczny jako marksizm apofatyczny
}

Tekst poświęcony jest problematyzującemu charakter współczesnych utopii cyklowi Terra Ignota Ady Palmer. Opisywanemu przez Palmer dwudziestemu piątemu wiekowi, w którym zniesiono płeć kulturową, państwa narodowe czy tradycyjny model rodziny, nie znosząc zarazem nierówności, przeciwstawiona zostaje postawa Utopian - niewielkiego ułamka fikcyjnej populacji. Choć ukazywana w powieściach rzeczywistość przez większość bohaterów traktowana jest jako utopia, Utopianie odmawiają przystania na nią, podejmując się nieustającej pracy w imię zerwania ze współczesnością i zobowiązując się poświęcić całe życie przyszłości. Utopia, ponieważ państwa pozbawione są terytoriów, nie może utworzyć na Ziemi przestrzennej enklawy i decyduje się na terraformację Marsa, choć nie dysponuje jednolitą wizją przyszłości i wspólnym celem poza opuszczeniem Ziemi. Działania Utopian nie są podejmowane w imię koherentnej wizji, a wypływają ze sprzeciwu wobec porządku faktycznego, znaturalizowanego przez większość społeczeństwa. Strategia Utopian omówiona zostaje jako przykład marksizmu apofatycznego, który postulował China Miéville. Niedostarczający pozytywnych projektów marksizm apofatyczny pozostaje potężnym narzędziem krytyki współczesności i bodźcem pobudzającym do działania.

Słowa kluczowe: utopia, marksizm apofatyczny, Terra Ignota, Ada Palmer, science fiction 
Klasyczne, formalistyczne ujęcia teoretyczne science fiction (oraz wyrosła z nich, do dziś żywa tradycja marksistowskich science fiction studies) traktowały ten gatunek jako z definicji antyhegemoniczny. Darko Suvin, dający początek nurtowi badawczemu kontynuowanemu między innymi przez Fredrica Jamesona, Gerry'ego Canavana czy Chinę Miéville’a, genezy science fiction upatrywał w utopii, sięgającej jeśli nie Apulejusza, to na pewno Thomasa Moore'a. Jak twierdził, „utopia stanowi heurystyczne narzędzie doskonałości, byt epistemologiczny, nie ontologiczny" (Suvin [1979] 2016, 66) ${ }^{1}$. Jej zadaniem w takim ujęciu jest umożliwić poddanie współczesnej rzeczywistości refleksji i wskazać odbiorcom możliwość jej zmiany za pośrednictwem obrazów odmiennej organizacji świata. Suvin dowodził, że

Obcy - utopianie, potwory lub po prostu odmienni nieznajomi - są lustrem człowieka tak samo, jak odmienny kraj jest lustrem tego świata. Ale to lustro nie tylko odbija, ale też przekształca, jest dziewiczym łonem i alchemiczną prądnicą: lustro jest tyglem. (Suvin [1979] 2016, 17)

Analogiczną funkcję utopii wskazuje Vincent Geoghegan, dowodząc, że utopia może być postrzegana jako

szkic lepszej przyszłości, „powinno być”, które przeciwstawiamy „jest”. Możliwość takiej przyszłości burzy samozadowolenie i pomaga przełamać bezruch istniejącego społeczeństwa, pokazując, że nie jest ani wieczne, ani archetypowe, a stanowi wyłącznie jedną formę spośród wielu. (Geoghegan 2008, 16)

Wychodzący z suvinowskich założeń Carl Freedman twierdził, że dialektyka rozpoznania i wyobcowania stanowi podstawowy mechanizm zarówno fantastyki naukowej, jak i marksizmu. Celem obu jest zniszczenie podtrzymujących obecny porządek społeczny iluzji i obnażenie arbitralności w tym, co znaturalizowane, tak by możliwe stało się stworzenie świata nowego i lepszego (Freedman 2009, 72-74). Jeśli przyjąć takie założenie, science fiction można by opisywać jako fabularyzowaną teorię krytyczną, a różnica pomiędzy utopią jako światem przedstawianym w dziełach fikcjonalnych a społeczną myślą utopijną zostaje niemal zatarta.

1 W wypadku wszystkich cytatów, gdy cytowane są publikacje anglojęzyczne - przekład filologiczny własny. Fragment książki Suvina (krótki esej Poetyka science fiction) został przełożony na język polski dwukrotnie - przez Barbarę Okólską już w 1989 roku i przez Krzysztofa M. Majaw 2018 roku. Dostępny po polsku fragment nie zawiera jednak wszystkich partii opracowania Suvina, do których się odwołuję. 
W dwudziestym wieku nawet popularna fantastyka naukowa, jak choćby serial Star Trek w swoich licznych odsłonach, często pełniła taką właśnie funkcję, oferując wizje kolejnych utopii wolnych od kapitalizmu i obrazy świata takiego, jakim mógłby być. W ostatnich dekadach dochodzi jednak do coraz bardziej widocznego załamania, szczególnie w odniesieniu do wyobrażeń o przyszłości. Canavan (2018) dowodzi, że główną funkcją SF - szczególnie tego adresowanego do młodzieży - staje się wytwarzanie skryptów poznawczych i behawioralnych, które pozwolą odnaleźć się w rzeczywistości po katastrofie klimatycznej. Nawet teksty kultury ukazujące świat, który jakimś cudem katastrofy uniknął lub się po niej podniósł - wielekroć stanowiące adaptacje starszych tekstów czy wznowienia wcześniejszych franczyz - coraz częściej odchodzą od prezentacji rzeczywistości radykalnie odmiennej od tej znanej z empirii. Skupiają się raczej na postępie technologicznym, rezygnując z wyobrażeń o towarzyszącej mu zmianie porządku społecznego. Kapitalizm i wynikająca z niego stratyfikacja społeczna nie tylko nie zostają w nowych tekstach zastąpione innym modelem, ale - jak pokazują chociażby nowe wcielenia Star Treka, w szczególności serial Picard ${ }^{2}$ - są wprowadzane i prezentowane jako obecne od zawsze (a więc znaturalizowane) w seriach do tej pory wobec kapitalizmu krytycznych. Rozciągający się na nasze wizje przyszłości realizm kapitalistyczny jawi się obecnie jako drugi obok katastrofizmu, przejawiającego się w narracjach postapokaliptycznych lub dotyczących wyczerpania zasobów (Canavan 2018) ${ }^{3}$, nurt dominujący w fantastyce naukowej - tak jakby gatunek powoli zatracał swoją zdolność do prezentowania programu pozytywnego.

2 Od dokonania w 2009 roku przez J. J. Abramsa rebootu franczyzy Star Trek nie tematyzował nierówności w kapitalizmie i nie odnosił się do tego zagadnienia, choć robił to od lat sześćdziesiątych dwudziestego wieku. W pierwszym sezonie Picarda (2020) kapitalizm - do tej pory obcy Zjednoczonej Federacji Planet, w której zaspokojenie podstawowych potrzeb było zagwarantowane, a praca miała służyć wzbogaceniu wewnętrznemu - pokazany został jako powszechnie panujący porządek. Nigdzie nie zostaje wyjaśnione, jak i kiedy kapitalizm wkroczył do Federacji.

3 Tendencje do ukazywania świata po katastrofie klimatycznej bądź świata na skraju wyczerpania zasobów uwidaczniają się w licznych dwudziestopierwszowiecznych tekstach kultury - Canavan wymienia jako przykłady superprodukcje (Wall-E, Igrzyska śmierci, Avengers: Wojna bez granic) i teksty nieco bardziej niszowe (między innymi Droga Cormaca McCarthy'ego, New York 2140 Kima Stanleya Robinsona, film Plastic Bag Ramina Bahraniego czy komiks Tutaj Richarda McGuire’a). W nurt postapokaliptyczny niewątpliwie wpisują się również cieszące się ogromną popularnością książki i serial The Expanse oraz powieść Toromorze Chiny Miéville’a. 
W tym tekście chciałabym zwrócić uwagę na fakt, że - jak pokazuje koncepcja marksizmu apofatycznego Chiny Miéville'a - program pozytywny nie jest konieczny, by dało się podjąć krytykę zastanego porządku. Skupię się na relatywnie słabo rozpoznawalnym fantastycznonaukowym cyklu Terra Ignota Ady Palmer. Cykl pozwala sproblematyzować (neo) liberalny charakter współczesnych utopii, wobec którego tylko via negativa może jawić się jako impuls do działania. Wyzwolenie z kapitalizmu w powieściach Palmer powiązane zostaje z ucieczką z planety. By rozważania na ten temat były możliwe, trzeba jednak dokonać pobieżnego opisu fikcyjnej rzeczywistości, której wąska grupa postaci się sprzeciwia. Dlatego też niniejszy artykuł będzie podzielony na sekcje odpowiadające różnym wydaniom utopii - od utopii liberalnej (którą stanowi świat przedstawiony w powieściach Palmer), przez utopię apofatyczną (której przedstawicielem jest jedna z opisanych w cyklu Pasiek), po utopię kosmiczną jako odpowiedź na niemożliwość ucieczki przed kapitalizmem na Ziemi.

\section{Utopia liberalna}

Na niezakończony jeszcze cykl Terra Ignota składają się powieści Do btyskawicy podobne (Too Like the Lightning), Siedem kapitulacji (Seven Surrenders), Zdecydowani na walkę (The Will to Battle) i mające się dopiero ukazać w listopadzie 2021 roku Perhaps the Stars (którego polski tytuł zapewne brzmieć będzie Być może gwiazdy). Pierwszy tom nominowany był do Nagrody Hugo, choć ostatecznie jej nie otrzymał. Mała popularność cyklu w środowiskach fanowskich wynika zapewne częściowo z tego, że został on napisany angielszczyzną stylizowaną na osiemnastowieczną (czego zresztą polskie tłumaczenia nie oddają w pełni). Początkowo opiera się na jukstapozycjach oraz permutacjach motywów znanych z literatury tego okresu, szczególnie literatury sentymentalnej, by z czasem, zbliżając się bardziej ku klasycyzmowi, zacząć w coraz większym stopniu naśladować Iliadę. Niewiarygodny narrator równolegle relacjonuje wydarzenia i wdaje się w spory z filozofami oświecenia: markizem de Sade'em, Jeanem-Jakiem Rousseau, Voltairem czy Thomasem Hobbesem. Niekiedy traktuje ich jako pełnoprawnych bohaterów, którzy otrzymują własne partie dialogowe, zaś postaci mityczne - jak Achilles czy Patroklos - zostają włączone w ontologię świata przedstawionego i mają kluczowy wpływ na kolejne wydarzenia. Dodatkową barierę dla 
odbiorcy może stanowić fakt, że same partie mimetyczne ${ }^{4}$, w szczególności dialogi, napisane są językiem nieprzystającym ani do modelu osiemnastowiecznego, ani do współczesnego. Postacie żyją w dwudziestym piątym wieku, w którym całkowicie zniesiono ideę płci kulturowej, co oznacza brak jakichkolwiek nieneutralnych płciowo zaimków. Sam narrator, usiłując odtworzyć język osiemnastowieczny, przypisuje bohaterom zaimki nacechowane płciowo w sposób niekiedy zupełnie arbitralny i oderwany zarówno od ich zewnętrznych cech płciowych, jak i tożsamości.

Zanik genderu to zaledwie jedna z wielu zmian, jakie przez wieki przeszło społeczeństwo w świecie przedstawionym. Dzięki automatyzacji czas pracy uległ skróceniu do dwudziestu godzin tygodniowo i osoby pracujące więcej - nazywane wokerami - robią to nie z konieczności, ale z powołania i cieszą się ogromnym szacunkiem. Profesjonalizacja doprowadziła do porzucenia idei rodziny zarówno wielopokoleniowej, jak i nuklearnej, wypartych przez basze - grupy dorosłych wykonujących wspólny zawód, podzielających swoje zainteresowania bądź darzących się nawzajem dostateczną sympatią, by zamieszkać razem i ewentualnie wychować potomstwo. Religia po wydarzeniu nazywanym Wojną Kościołów została zepchnięta całkowicie do sfery prywatnej i poza specjalnymi rezerwatami (takimi jak Watykan) panuje zakaz rozmawiania o niej z kimkolwiek oprócz przeszkolonych i nieujawniających własnych przekonań senseistów, pełniących równocześnie funkcję terapeutów i teologów. Pierwsze dwa tomy cyklu opatrzone są nawet zakorzenionymi w świecie przedstawionym trigger warnings, do których obok zrozumiałych kategorii takich jak „gwałt; wzmianki o seksie z użyciem przemocy” włączone zostają ostrzeżenia: „obszerne i długie dyskusje na tematy religijne (...); teologiczna brutalność; (...) religijne przekonania realnych, żyjących osób” (Palmer 2019a, 6).

Pod wpływem postępu technologicznego, w wyniku którego wynaleziono znacznie szybsze niż dotychczas środki transportu, doszło do rozkładu państw narodowych. Jak w roku 2131, w obliczu perspektywy wybuchu kolejnej wojny światowej, deklarował król Hiszpanii, „to absurd zmuszać kogoś, kto ma ojca w jednym kraju, matkę w drugim, urodził się w trzecim, a pracuje w czwartym, do deklarowania lojalności wobec arbitralnie określonego geograficznego państwa” (Palmer 2019b, 125). Właściciele trzech największych firm transportowych, za którymi stała

4 W rozumieniu mimesis zaproponowanym przez Marie-Laure Ryan (2012) jako przeciwstawnej diegesis. 
„trzecia część ludności świata, i to ta najbogatsza” (Palmer 2019b, 122), wypracowali zatem następujące stanowisko:

Co to jest „naród”? (...). To grupa ludzi połączonych więzią. Nie więzią krwi i geografii, lecz przyjaźni i zaufania. (...) Amerykanie, Ameryka nie jest już waszym państwem. Są nim przyjaciele, którzy żyją i pracują razem z wami, w Afryce, Europie, Azji, Australii, w obu Amerykach i we wszystkich zakątkach Ziemi. Waszymi rodakami są ci, którzy chodzili z wami do szkoły, którzy kibicowali tym samym drużynom, dorastali z wami, dzielili się z wami osobistymi sekretami przez Internet, a dzisiaj podzielą się z wami chlebem w waszym domu, na którymkolwiek kontynencie się on znajduje. Waszym państwem jest organizacja, którą wybraliście, by broniła waszej rodziny i własności (...). (ibid,, 123)

Pojęcie nacji zostało w świecie przedstawionym zastąpione przez dobrowolnie wybieraną, pozbawioną terytorium i często działającą na wzór korporacji Pasiekę, przynależność do której można zmienić, a której wybór opiera się na wyznawanych wartościach i preferowanym systemie władzy. Największą z siedmiu istniejących w dwudziestym piątym wieku Pasiek stanowią przywiązani do tradycji i odwołujący się do idei Cesarstwa Rzymskiego Masoni pod dyktaturą cesarza, drugą - specjalizujący się w pomocy medycznej, opiece, edukacji, działalności charytatywnej i pracy afektywnej, podejmujący decyzje poprzez demokrację bezpośrednią Kuzyni. Z kolei wywodzący się bezpośrednio z korporacji o tej samej nazwie Mitsubishi, którzy wchłonęli Greenpeace, zainteresowani są wielkim biznesem, a ich główne zasoby stanowią ziemia i nieruchomości. Rozmiar posiadanego obszaru bądź liczba nieruchomości decydują o wadze głosu danego obywatela. Nazwa stanowiących demokrację parlamentarną Europejczyków może być myląca, bowiem do Pasieki przynależą wszystkie osoby wciąż identyfikujące się z jakąkolwiek grupą narodową, niezależnie, czy wywodzi się ona z terytorium Europy. Kładący nacisk na szeroko pojętą ambicję, dążenie do sukcesu na dowolnym polu $\mathrm{i}$ indywidualne osiągnięcia Humaniści stanowią w teorii demokrację, ale u władzy znajdują się celebryci, zazwyczaj arystokratycznego pochodzenia. Wśród nielicznych i skupionych na psychologii, kognitywistyce i cybernetyce Gordian panuje akademicka merytokracja i głową struktury politycznej jest rektor najważniejszej uczelni. Najmniejszą i najbardziej odstającą od reszty Pasiekę stanowi traktowana z niechęcią lub pobłażaniem Utopia, na której chciałabym się skupić w dalszej części wywodu. 
Opisywany przez Palmer dwudziesty piąty wiek zdaje się realizacją (a może raczej parodia) liberalnych fantazji - od trigger warnings, przez zanik płci kulturowej, odejście od tradycyjnego modelu rodziny, po rozpad państw narodowych w imię dobrowolnej przynależności do wybranych struktur. Jak wskazuje jedna z postaci, „nasz świat jest daleki od doskonałości, ale ludzie nigdy nie byli szczęśliwsi, zdrowsi, bardziej produktywni, wolni i równi” (Palmer 2020, 57). W drugim tomie serii do wiadomości publicznej trafia jednak informacja, że od setek lat pokój społeczeństwu zapewniają zatwierdzane przez władze części Pasiek zabójstwa tysięcy niewinnych osób. Ich śmierć pozwalała uzyskać stabilizację polityczną, a ich status społeczny był na tyle niski, by zgon nie wzbudził podejrzeń. Jeden z bohaterów, cenzor Vivien Ancelet, wygłasza wówczas płomienną mowę, której zadaniem jest powstrzymanie wybuchu rewolucji:

Zanim posłuchacie Snipera albo Tulliusa Mardiego, którzy mówią wam, że krwawa rewolucja jest jedyną drogą mogącą prowadzić do lepszego świata, uświadomcie sobie, że odrzucacie utopię! (...) Osiągnęliśmy wszystko, o co walczyły poprzednie pokolenia. (...) Gdybym miało wehikuł czasu, mogłobym przeniesś się w przeszłość i odszukać któreś ze starożytnych królów, wszystko jedno które, i pokazać mu nasz świat. Ropłakałoby się z zazdrości na widok tego, co mają nawet najskromniejsi z nas - baszobudynek ciepły zimą, a chłodny latem, wygodne ubrania, urządzenia wykonujące pracę tysiąca służących, wolny wybór baszu, wolny wybór małżonka, wolny wybór praw, które nami rządzą, oraz pracy, którą [sic!] sprawia nam satysfakcję i musimy na nią poświęcać tylko dwadzieścia godzin tygodniowo, a przez resztę życia możemy słuchać muzyki dostępnej po naciśnięciu guzika, czytać takie książki, jakie zapragniemy, podróżować bezpiecznie po świecie i jeść dobrze jak królowie, a nawet lepiej! (...) Nasz świat jest utopią. Nie jest doskonały ani ukończony, niemniej pozostaje utopią w porównaniu ze wszystkimi poprzednimi epokami. (Palmer 2019a, 354-355)

Wypowiedź Anceleta ${ }^{5}$, wraz z kończącym ją apelem: „Potrzebujemy powolnych, spokojnych zmian, by uczynić nasz dobry świat lepszym, a nie wojny czy rewolucji, które zniszczyłyby wszystko" (ibid., 355), może być potraktowana jako credo liberalizmu.

Stosowane przez Anceleta rozumienie utopii jest bardzo interesujące z kilku względów. Po pierwsze, utopia jest tu kategorią relatywną. Warunkiem nadania tego miana określonej wersji rzeczywistości nie jest już jej

5 W wypadku postaci, które prywatnie identyfikują się z jakąś płcią kulturową, pozwalam sobie stosować formy gramatyczne korespondujące $\mathrm{z}$ ich genderem. 
Wszelkie zmiany,

z wprowadzeniem

Pasiek na czele, wcale nie zniosły nierówności.

Pozwoliły jedynie

wybierać, z czego

dokładnie doświad-

czana przez jednostkę nierówność ma wynikać, a zatem wytwo-

rzyły w podmiotach

przekonanie, że ich pozycja jest wynikiem własnych decyzji. doskonałość, ale sam fakt, że jest ona lepsza od tego, co ją poprzedzało. $\mathrm{Z}$ tej nowej, zadowalającej dla Anceleta - i przeważającej większości populacji - rzeczywistości nie wyeliminowano cierpienia, którym okupiony jest dobrobyt bardziej uprzywilejowanych. Nawet świadomość śmierci tysięcy - ginących w imię utrzymania status quo - nie zmienia długotrwale tego samozadowolenia. Po drugie, opisywana przez Anceleta rzeczywistość z uwagi na jego dobór słownictwa musi być odnoszona do innych, historycznych utopii - z dziełem Thomasa Moore'a na czele. Już w utopii Moore’a jednak nie było miejsca dla pieniądza, tymczasem w opisywanym przez Palmer dwudziestym piątym wieku nie tylko istnieją waluta i gospodarka kapitalistyczna podobna nam współczesnej, ale także stan posiadania najwyraźniej wciąż determinuje pozycję społeczną (w najbardziej jawny sposób wśród plutokratycznych Mitsubishian). Jest rzeczą znamienną, że w cytowanym wcześniej przemówieniu król Hiszpanii jako państwo definiuje organizację, która ma za zadanie bronić rodziny i własności. Wszelkie zmiany, z wprowadzeniem Pasiek na czele, wcale nie zniosły nierówności. Pozwoliły jedynie wybierać, z czego dokładnie doświadczana przez jednostkę nierówność ma wynikać, a zatem wytworzyły w podmiotach przekonanie, że ich pozycja jest wynikiem własnych decyzji.

Po trzecie natomiast - i najbardziej kluczowe - Ancelet używa słowa „utopia”, które w świecie przedstawionym jest obciążone dodatkowymi znaczeniami. Jak nawołuje, „[n]ie dajcie się zmamić faktowi, że jedna z Pasiek używa tego słowa jako swej nazwy. Ich marsjańska kolonia, ich kosmiczne fantazje nie są utopią. Utopia jest tutaj!" (Palmer 2019a, 354). Zadowolenie z obecnego porządku jako najlepszego z dostępnych prezentowane jest tu jako słuszne i skontrastowane zostaje z projektem najmniejszej z Pasiek - a nawet z samym faktem jej istnienia.

\section{Utopia apofatyczna}

W wypadku Utopian sama nazwa Pasieki sugeruje, że zastany porządek nie jest akceptowany jako idealny i ostateczny. Liberalnej „utopii” Anceleta - w której złagodzono największe patologie systemu opartego na nierównościach na tyle, że wygodniej jest już go nie kontestować - przeciwstawiona zostaje jakaś inna utopia.

Utopia (zapisywana wielką literą jako nazwa własna Pasieki) to społeczność, która zobowiązuje się wszystkie swoje siły poświęcić odległej przyszłości, wiązanej głównie z czasochłonną terraformacją Marsa. W pierwszych słowach składanej przy wstąpieniu do Pasieki przysięgi obywatel 
„wyrzeka się prawa do samozadowolenia” (Palmer 2020, 401), a w ostatnich - zobowiązuje się wyprowadzić ludzkość od śmierci ku gwiazdom. Utopianie są wokerami i wykonują bardzo różne zawody, ale stereotypowo są przede wszystkim naukowcami lub artystami. Posługują się specyficzną mową (U-speak), w ewidentny sposób nawiązującą do dwudziestowiecznego żargonu fanów science fiction czy, rzadziej, szeroko pojętej fantastyki. Występują w towarzystwie u-bestii - stworzeń będących wynikiem inżynierii genetycznej lub robotyki, takich jak smoki czy jednorożce. Twarze Utopian zakryte są zawsze wizorami (visors, z niewiadomych przyczyn przekładane na polski jako „woalki”), a na ich płaszczach wyświetlają się bardzo zróżnicowane interaktywne projekcje obcych światów.

Fascynacja Utopii science fiction jest zjawiskiem interesującym. Decyzja Palmer o powiązaniu Pasieki z tym gatunkiem była nieprzypadkowa i ma charakter metaliteracki - dość wspomnieć o roli przypisywanej fantastyce naukowej w klasycznych science fiction studies. Fascynacja Utopian przyszłością przypomina o możliwości innej organizacji świata, pełniąc funkcję, jaką przypisywał science fiction kontynuujący suvinowską tradycję Jameson. W Archeologiach przyszłości szczególnie eksponuje on właśnie ideę przyszłości, zwracając uwagę na to, że „[w]yszukane strategie niebezpośredniości są (...) konieczne, jeśli mamy przedrzeć się przez naszą izolację i »doświadczyć«, faktycznie w istocie po raz pierwszy, owej »teraźniejszości«, która jest przecież wszystkim, co mamy” (Jameson 2011a, 340).

Zgodnie z modelem badacza, historyczność to „postrzeganie teraźniejszości jako historii, czyli taki stosunek do teraźniejszości, który ją uniezwykla i pozwala nabrać do niej dystansu" (Jameson 2011b, 290). Fantazmat przyszłości w science fiction istniałby zgodnie z takim modelem nie jako przedmiot faktycznej futurologii, ale wyłącznie po to, by stanowić punkt odniesienia, w relacji do którego opisywać można teraźniejszość: „Science fiction ustanawia i umożliwia wyjątkową strukturalną metodę zrozumienia teraźniejszości jako historii” (Jameson 2011a, 342). Podjęta przez Palmer decyzja o posłużeniu się osiemnastowiecznymi modelami narracji i językiem w tym kontekście staje się szczególnie znacząca, bowiem, jak wskazują choćby Roberto Esposito (2015, 95-96) czy Michel Foucault (2000, 289), to w oświeceniu wykształciła się koncepcja radykalnej historyczności rozumianej jako przygodność i arbitralność otoczenia i samego podmiotu. Oświecenie miało być zdolnością podjęcia krytyki własnej - historycznej i przygodnej - pozycji i wyobrażenia sobie świata zorganizowanego inaczej. Science fiction jednak, jeśli zawierzyć Jamesonowi, pełni funkcję szczególną, najbardziej eksponując 
przyszłość jako kontekst czyniący z teraźniejszości historię - nawet jeśli kształt przyszłości jeszcze nie jest zdeterminowany. Palmer posługuje się całą serią chwytów, które mają podkreślać historyczny wymiar czasu poczynając od archaizacji, przez ciągłe odwołania do tradycji i wydarzeń znacznie wcześniejszych od osiemnastowiecznych, po kreację narratora. Ten, choć przeznaczono mu funkcję kronikarza wydarzeń rozgrywających się w ciągu zaledwie kilku dni, w jednej scenie zwraca się do postaci z przeszłości, wywołując duchy oświeceniowych filozofów i tocząc z nimi spory, by w następnej kierować swoje słowa do czytelnika z odległej przyszłości i próbować przybliżyć mu własną, dwudziestopiątowieczną rzeczywistość jako już egzotyczną i zapomnianą ${ }^{6}$. W ten sposób za sprawą zakorzenionego w świecie przedstawionym i będącego głównym bohaterem narratora uruchamiana jest Jamesonowska funkcja przyszłości jako punktu zarazem nieznanego i dostarczającego nowej perspektywy, z której dokonywałoby się oglądu dnia dzisiejszego.

Suvin - uznając, że o funkcji krytycznej science fiction decyduje zdolność tekstu do pokazania rzeczywistości radykalnie odmiennej eksponował rolę organizującego narrację novum, czyli możliwej z punktu widzenia nauki zmiany (technologicznej, społecznej, ekonomicznej etc.) wobec świata nam znanego. To na niej miałby się opierać kreowany przez twórcę świat:

Związek [novum] z istotną nowinką będzie taki sam, jak związek z corocznym pseudo-novum ${ }^{7}$ "nowych i lepszych” (...) modeli samochodów czy stylów ubioru z faktycznie radykalną nowością, taką jak rewolucja społeczna i zmiana paradygmatu naukowego tworzące, dajmy na to, poprawiający jakość życia transport czy ubiór. (...) W skrócie, novum jest fałszywe, jeśli nie uczestniczy w jakiś sposób w tym, co Bloch nazwał „frontem procesu historycznego” - który dla niego (i dla mnie) jako marksisty znaczy proces ostatecznie związany z walką o przełamanie alienacji ludzi doświadczanej w ich życiu społecznym. (Suvin [1979] 2016, 90)

U Palmer Cato Weeksbooth, marzący o Utopii naukowiec zmuszony do wstąpienia do niechcianej Pasieki i do partycypacji w zbrodniach podtrzymujących obecny porządek, wyjaśnia z goryczą:

6 W akapicie otwierającym pierwszą część cyklu narrator zwraca się do czytelnika i zapewnia go o jego zdolności do zrozumienia nacechowanego płciowo języka „bez względu na to, czy [jest] moim współczesnym, nadal zdumionym nadejściem nowego porządku, czy też historykiem patrzącym na moje dwudzieste piąte stulecie tak, jak ja patrzę na osiemnaste" (Palmer 2019b, 9).

7 Pojęcie pseudo-novum i jego zapis w tej formie pojawiają się u Suvina. 
W szkole mówią tylko, że nauka jest użyteczna. Naucz się trochę geometrii, a będziesz mogło zaprojektować budynek, naucz się trochę chemii, a będziesz umiało wyprodukować plastikową torbę. (...) Już mamy plastikowe torby, wygodne krzesła i autoloty, mieliśmy je od stuleci i nie stają się coraz lepsze, bo i tak działają zadowalająco i nikomu nie zależy, by zastąpić je lepszymi, tylko żeby były tańsze albo dołączano do nich więcej gier. (Palmer 2019a, 414)

„Plastikowe torby, wygodne krzesła i autoloty” stanowią idealne odbicie „»nowych i lepszych" modeli samochodów” Suvina, a więc zaledwie pseudo-novum. W ramach takiego porządku, jak formułował to Mark Fisher (2020, 11), „przyszłość będzie nieść ze sobą tylko powtórzenie, rekombinację". Opisywany - czy raczej kontestowany - przez Cato porządek opiera się na (przesuniętym o kilka stuleci) realizmie kapitalistycznym, czyli atmosferze, w której niemożliwą do pomyślenia staje się już koherentna alternatywa wobec zastanej rzeczywistości, a postęp utożsamiony zostaje z nieznacznym udoskonaleniem już istniejącej technologii bądź wprost powtarzaniem sprawdzonych rozwiązań ${ }^{8}$. Brak wizji rewolucyjnie nowego porządku, który mógłby rozwinąć się w przyszłości, sprawia, że zaburzeniu ulega poczucie czasu. Konsekwencją zaniku przyszłości jako idei staje się rozciągnięcie teraźniejszości na dekady - czy właściwie, w wypadku świata przedstawionego u Palmer - na stulecia, traktowanego jako najwyższa wartość i chronionego za wszelką cenę status quo.

W powieściach ten stan rzeczy okazuje się dla 96 procent populacji nie idealny, ale dostatecznie zadowalający, ponieważ najbardziej rażące nierówności należą już do odległej przeszłości. Funkcjonowanie w tej nowej rzeczywistości - nawet jeśli okupione krzywdą tysięcy - jest dla ogromnej większości obywateli wygodne, szczególnie gdy porównywać je do życia ich przodków. Jak wskazywał w przywoływanej przez Fishera wypowiedzi Alain Badiou (2001), „obrońcy zastanego porządku nie mogą nazywać go idealnym bądź wspaniałym, więc postanowili tłumaczyć, że wszystko poza nim jest straszliwe”. Światem „wszystkiego poza nim” w wypadku cyklu Palmer nie są inne obszary geograficzne, a właśnie przeszłość, którą, jak pokazuje przemowa Anceleta, przywołuje się, by przez kontrast uczynić teraźniejszość świata przedstawionego dużo łatwiejszą do akceptacji. Ponieważ większość obywateli nie jest w bolesny sposób obciążona nierównościami panującymi w opisywanym przez

8 Koncepcja Fishera jest, rzecz jasna, dużo bardziej złożona, jednak kolejne opisywane przez niego zjawiska - czy też aspekty realizmu kapitalistycznego prezentowane są przez filozofa jako konsekwencje stanu wyjściowo definiowanego właśnie jako niezdolność wyobrażenia sobie alternatyw. 
Palmer świecie bądź jest przekonana, że wynikają one z indywidualnego wyboru, nie odczuwa się już potrzeby zmiany. Nie ma zatem powodu, by zmianę projektować. Krytyka tego liberalnego porządku możliwa okazuje się tylko z pozycji Utopii, która nie porównuje rzeczywistości do przeszłości, ale do wyobrażonych, możliwych przyszłości. W tym sensie Pasieka spełnia funkcję typową dla utopii literackich, określaną

Krytyka tego liberalnego porządku możliwa okazuje się tylko z pozycji Utopii, która nie porównuje rzeczywistości do przeszłości, ale do wyobrażonych, możliwych przyszłości. przez Thomasa Moylana jako „utopia krytyczna”. Opisywane przez teoretyka teksty realizujące tę funkcję „kwestionowały zasadność antyutopijnego odrzucenia utopijnej myśli i utopijnej praktyki; odmawiały akceptacji obecnego porządku społecznego jako "utopijnego«, stawiając w ten sposób opór próbom stłumienia prawdziwie utopijnych działań" (Moylan 2000, 82).

Noszone przez Utopian wizory nie tylko odróżniają ich od reszty ludzi, ale - przede wszystkim - przez cały czas wyświetlają nad każdym przedmiotem i każdą osobą znaczniki, które wskazują, co wymaga naprawy i ulepszenia. Jak wyjaśnia jedna z postaci, „to nieskończona lista zadań. Trudno jest pozostać rasą wokerów w tak wygodnym świecie" (Palmer 2019a, 394). Utopia to, w przeciwieństwie do wszystkich pozostałych Pasiek, Pasieka malkontentów, świadomie powstrzymujących się od uznania czegokolwiek w otoczeniu za akceptowalne. „Nie moglibyśmy tak ciężko pracować dla swych utopii, gdybyśmy pozwolili sobie uwierzyć, że są realne" (ibid.) - oświadcza jedna z postaci. Jej dobór słów jest bardzo istotny, bowiem „utopia” - jako rzeczownik pospolity, nie nazwa Pasieki - występuje tu w liczbie mnogiej.

Najmniejsza z Pasiek angażuje się w politykę w sposób dla pozostałych najczęściej niezrozumiały i często zaskakujący, a jej najpoważniejszą bronią jest strajk generalny (Palmer 2020, 61). Opierającemu się na głosowaniach nakładających się na siebie sieci i zespołów zwanych „konstelacjami”, zdecentralizowanemu i niehierarchicznemu ustrojowi Utopian trudno jest przyporządkować jakąkolwiek współczesną kategoryzację, ale najbliższy wydaje się on anarchosyndykalizmowi. O poglądach Utopii trudno rozstrzygać z jednego względu - Pasieka jako taka ich nie ma. Choć wszyscy jej członkowie decydują się poświęcić życie budowaniu przyszłości poza Ziemią i odrzucają zastany porządek, każdy robi to w imię całkowicie odmiennej wizji jego zmiany. Płaszcze Utopian, o których była wcześniej mowa, nie są tylko kolejnym elementem, który pozwala grupie wyróżnić się na tle reszty społeczeństwa i prowadzi do egzotyzacji mniejszości. Jak przy pierwszym pojawieniu się Utopian wskazuje narrator,

[p]łaszcz jednej z dwóch stojących przede mną w zaułku osób pokazywał obraz Miasta Przyszłości zbudowanego w kosmosie. Znajdujący się za nami pałac 
pływał w morzu gwiazd, rośliny wyposażono w zbieracze tlenu, a autoloty w żagle słoneczne nadające im wygląd latających ryb. Drugi płaszcz pokazywał pałac jako pogrązające się w bagnie ruiny. Kamienie jego murów postarzały się o tysiąc lat, a w promieniach słońca wygrzewały się osobliwe stworzenia przypominające średniowieczne wyobrażenia smoków (...). Utopia znaczy „nigdzie” i dlatego wszyscy Utopianie spowijają się w swe ulubione wyimaginowane krajobrazy. (Palmer 2019b, 185-186)

Płaszcze Utopian nie tyle nawet pokazują „ulubione wyimaginowane krajobrazy”, ile najczęściej reagują na obiekty w bezpośrednim sąsiedztwie, projektując na nie własne wizje przyszłości danego członka Pasieki. Przykładowo, płaszcz dążącego do przyspieszenia wybuchu nieuniknionej wojny Apolla Mojave pokazywał ruiny, rannych i, zgodnie z przewidywaniami zdziesiątkowania populacji, tylko co którąś z mijanych osób (Palmer 2019a, 164). Zadziwiające bogactwo obrazów ujawniających się na płaszczach Utopian nie świadczy tylko o ich wyobraźni, ale przede wszystkim o mnogości konkurencyjnych wizji przyszłości (zawsze wyraźnie odmiennych od zastanego porządku), do których obywatele Pasieki zmierzają. Wizji jest bowiem niemal tyle, ile samych Utopian. Jak zwracał uwagę Jameson,

Najbardziej charakterystyczna science fiction nie próbuje poważnie wyobrażać sobie „rzeczywistej” przyszłości naszego systemu społecznego. Jej wielorakie imitacje przyszłości spełniają raczej zupełnie inną funkcję, która polega na przekształcaniu naszej teraźniejszości w określoną przeszłość czegoś, co ma dopiero nastąpić. (Jameson 2011a, 340, wyróżnienie własne)

Utopia jako Pasieka oparta zostaje zatem o miliony sprzecznych wyobrażeń. Ich jedyną cechą wspólną jest odmienność od liberalnej utopii reszty społeczeństwa, niezainteresowanego snuciem nowych wizji, skupionego na zachowaniu status quo i co najwyżej spierającego się o to, w jaki sposób porządek można najskuteczniej utrwalić. Utopianie wspólnie dążą do terraformacji Marsa, jednak nie panuje wśród nich zgoda, jak życie na Marsie miałoby być zorganizowane. Mimo tego braku spójnego programu pozytywnego, Utopia wciąż jednak funkcjonuje, wszystkie wysiłki kierując ku przyszłości, której członkowie Pasieki zapewne nie dożyją - bez rozstrzygania o jej kształcie, a jedynie z założeniem, że będzie ona odmienna od ich teraźniejszości. Moylan wskazuje, że przedmiotem refleksji utopii krytycznych - których rolę w cyklu Palmer pełni fikcyjna Pasieka - jest „świadomość ograniczeń tradycji utopijnej, przez co teksty te odrzucają utopię jako instrukcję [blueprint], zachowując ją 
jako marzenie" (Moylan 1986, 10-11)9. Tytuł cyklu Terra Ignota, w trzecim tomie wyjaśniony jako nazwa jednego z kruczków w prawie międzypasiekowym, odnosi przede wszystkim do wymarzonego przez Utopian Marsa i do przyszłości jako terytorium nieznanego, a zarazem leżącego w centrum narracji.

Amorficznej kontestacji liberalnego porządku, która podparta jest mglistymi wyobrażeniami o celu, do którego Utopia zmierza, nie można rozpatrywać w kategoriach jakichkolwiek wariantów socjalizmu czy komunizmu - a w każdym razie ich pozytywnych wersji. Działania Utopian, choć realizowane wspólnie, pozbawione są i wspólnego celu, i wspólnej wizji, w imię której są podejmowane. Projekt Utopii jest negatywny, w tym znaczeniu, że przyszłość ma być odmienna od tego, co znają obywatele Pasieki i do tego ograniczają się ich współdzielone założenia.

Jak dowodził China Miéville (2019),

możliwe i niewyrażalne przyszłości, utopijne i inne, stanowią funkcje naszej straszliwej i niewyrażalnej teraźniejszości. I my jesteśmy funkcjami dialektycznej, niewysłowionej totalności, która obejmuje i je, i nas. W tej sytuacji apofatyka jest w centrum nie tylko naszej rzeczywistości społecznej, ale i naszej sprawczości.

Miéville, sam zresztą będący i autorem, i teoretykiem science fiction, sięgnął tu po pojęcia kluczowe dla teologii, a w szczególności mistyki. Teologia katafatyczna (pozytywna) opiera się na opisywaniu bóstwa i jego przymiotów, natomiast za apofatyczną stoi założenie, że nie są one zrozumiałe dla człowieka lub wyrażalne w ludzkim języku. Z tej perspektywy możliwe jest tylko mówienie o tym, czym i jakim Bóg nie jest. Miéville (2019), zwracając uwagę na tę samą historyczność, o której pisał choćby Jameson, stwierdza: „nasze myślenie jest funkcją naszej rzeczywistości: to, co poza nią, z definicji jest niewyobrażalne”. Wychodząc z tego założenia i wskazując na naszą historycznie i ekonomicznie

9 Podobne ujęcie proponuje Ruth Levitas (2013, 18-19), pisząca o „utopii jako metodzie, a nie celu" - nie tyle jednak metodzie heurystycznej (jak traktowałby ją Suvin), ile konstruktywnej. Dla Levitas myślenie utopijne umożliwia stworzenie wielu złożonych scenariuszy przyszłości, które mogą - i winny - zostać poddane demokratycznej debacie i które muszą być traktowane jako tymczasowe, mgliste i robocze, jako że istnieje różnica pomiędzy tym, co możemy sobie wyobrazić, a tym, co możemy sobie wyobrazić jako możliwe do zrealizowania. Utopia rozumiana jako metoda zakłada mnogość i możliwość ciągłej zmiany postulowanych przyszłości. Ujęcie takie pozwala uwolnić się od chętnie powielanej kliszy utopii jako jednoznacznie wiodącej do terroru ze względu na swój zamknięty, totalny i nieelastyczny charakter. 
uwarunkowaną pozycję i związane z nią ograniczenia („Kapitalizm jest katastrofą, wycieńczającą, brutalną, nieustępliwą, nie da nam chwili wytchnienia i jest, kurwa, za głośny” [Miéville 2019]), Miéville proponuje milczenie. Niemożliwym jest, twierdzi, w pełni oddać niepojętą i niesamowitą potworność (teoretyk używa kolejno słów uncanny i monstrous jako odpowiedników unheimlich i ungeheuer) Kapitału. Słowa wobec jego niewyrażalnej totalności zawodzą i nie da się jej opisać; przede wszystkim jednak krępuje ona język, gdy chce się mówić o tym, co mogłoby znajdować poza nią. Komunizmu nie da się opisać; kapitalizm jest niewyobrażalny [Communism is unsayable: capitalism is unspeakable] (ibid.).

Choć teoretyk stwierdza, że apofatyka staje się symptomem kryzysu, uznaje ją jednocześnie za strategię adaptacyjną. Zarazem podkreśla, jak niewiele i niechętnie sam Marks, skupiony na krytyce współczesności, pisał o społeczeństwie bezklasowym. Analogicznie, Peter Frase w Czterech przyszłościach zwraca uwagę, że:

[c]hociaż Karl Marks jest najbardziej znany jako autor Manifestu komunistycznego, to nie napisał on wiele na temat treści społeczeństwa komunistycznego. Czasami zajmował się przejściowym okresem socjalistycznym, w którym robotnicy przejęliby istniejące środki wytwórcze i nimi kierowali. Nie miał to być jednak ostateczny cel polityczny. Tym celem był komunizm, który przekraczał pracę najemną i czas wolny. Wykraczał znacząco poza świat pracy, jakim go rozumiemy. Marks sądził jednak, że napisanie zbyt wiele na temat tego, jak komunizm będzie ostatecznie wyglądał, byłoby naiwnym ćwiczeniem z wymyślania przepisów „dla kuchni przyszłości”. (Frase 2018, 37)

Marksizm apofatyczny nie ma zatem spójnego projektu pozytywnego i nie przedstawia wizji przyszłości, do której miałby dążyć - ale też nie musi tego robić. Przyszłość jest niewyrażalna i jej opisowi może służyć tylko via negativa. Jak dowodzi Miéville (2019), wytykane lewicy przez konserwatystów niespójność i brak koherentnej wizji alternatywy „świadczą o szydercach. To ich wyobraźnia jest zbyt uboga, ślepa nie tylko (w przypadku antysocjalistów) na konieczność lepszej przyszłości, ale i na jej absolutną odmienność".

Krępującą język, pełną sprzeczności totalność Kapitału Miéville określa jako numinotyczną. Przywołuje tu wypracowaną przez Rudolfa Otta (1999) kategorię numinosum - świętości i mocy, które, wymykając się racjonalizmowi (czy raczej działając wbrew niemu), wywołują w podmiocie zarazem fascynację i paraliżujące przerażenie. Numinosum nie może być w pełni wyrażone, a jedynie sygnalizowane w najlepiej do

Marksizm apofatyczny nie ma zatem spójnego projektu pozytywnego i nie przedstawia wizji przyszłości, do której miałby dążyć - ale też nie musi tego robić. 
niego przystosowanym języku mitu. Ten tylko język Kapitał pozostawia podmiotom, by próbowały mówić o jego totalności lub o jeszcze bardziej obcej totalności tego, co poza nim.

Trudno też nie rozpatrywać w kategoriach mitu przywiązania Utopian, funkcjonujących w całkowicie zsekularyzowanym świecie, do fantastyki i najbardziej naiwnego science fiction (przez Suvina $[<1979>$ 2016, 70] zresztą kategoryzowanych, wraz z mitem, jako „gatunki metafizyczne"). To powiązanie z myśleniem mitycznym lub religijnym staje się szczególnie ewidentne, gdy wziąć pod uwagę fakt, że w dwudziestym piątym wieku poziom rozwoju nauki stoi w jawnej sprzeczności z wyobrażeniami dawnej futurologii, a w Pasiece jest tak wielu naukowców. Jak wyjaśnia narrator, nawet imiona Utopian, zazwyczaj będące imionami dawnych wynalazców, astronautów lub postaci z tekstów science fiction, są „wzięte z ich kanonu, jak w dawnych czasach Europejczycy brali swoje z listy świętych" (Palmer 2019b, 186). Dwunasty kwietnia, rocznica lotu kosmicznego Gagarina, to „wielkie święto, największe, dzień Świętego Jurija” (Palmer 2020, 76). W obrębie samego świata przedstawionego imaginarium fantastyki naukowej i ery sputników staje się jedynym, ułomnym środkiem krytyki rzeczywistości. Zarazem, zastępując bohaterom dawną mitologię, okazuje się jedynym sposobem na przywołanie obrazów rzeczywistości odmiennej, nawet jeśli nie ma ona dużo wspólnego z realistycznymi przewidywaniami dotyczącymi przyszłości. Podobną funkcję może pełnić tutaj lokowanie wszelkich nadziei w osiedleniu się na Marsie. Jest to cel tak odległy, że dla współczesnych narratorowi Utopian zupełnie nierealny, a wyrazić go można tylko w języku mitu Pasieki: pulpowego science fiction.

W świecie przedstawionym to cała skupiona na nieosiagalnej przyszłości Pasieka zaczyna pełnić funkcję przeznaczaną w naszej rzeczywistości fantastyce naukowej jako gatunkowi. Wprowadzenie Utopii do fabuły można rozpatrywać w kategoriach autotematycznego eksperymentu Palmer. Pisarka co krok podważa futurologiczny status swoich opisów dwudziestego piątego wieku, wprowadzając do narracji istoty i wydarzenia nadnaturalne. Relacje narratora, podporządkowującego wydarzenia logice Iliady, stają się z czasem coraz bardziej niewiarygodne - jakby faktyczna przyszłość gatunku ludzkiego nie mogła być opisana bez odwołań do herosów czy boskiej interwencji. Imaginaria opowiadającego o naszej przyszłości narratora (mitologia grecka) i fantazjujących o swojej przyszłości Utopian (mitologia stworzona w oparciu o dwudziestowieczną fantastykę) są niespójne z wiedzą naukową, nieracjonalne i nie mogą być traktowane jako realistyczne ani przez czytelników powieści, ani przez dążących do postępu naukowego członków najmniejszej 
Pasieki. Wcale jednak nie muszą - nie mają bowiem oferować realistycznego i spójnego obrazu osiągalnej przyszłości, ale przypominać w ogóle o istnieniu alternatywy. Całkowita rezygnacja z katafatyki nie oznacza zgody na obecny stan rzeczy.

\section{Utopia kosmiczna}

Archetypiczna utopia Moore’a, jeśli rozpatrywać ją nie jako krytykę współczesności autora, ale jako państwo stanowiące część świata przedstawionego, powstać mogła dzięki odgrodzeniu się od reszty świata. Suvin ([1979] 1988, 40) utopię definiował jako „otoczone, odizolowane miejsce" (kursywa oryginalna). Jameson, choć utopię traktuje nie w kategoriach terytorialnych, ale jako przestrzeń dyskursywną tworzącą wyrwę w doświadczeniu życia społecznego, określa ją jako enklawę. Warunkiem istnienia utopii jest wytyczenie jej granic i oderwanie jej od świata zewnętrznego (Jameson 2011a, 11-25). W jaki jednak sposób wytworzyć terytorium w świecie, w którym nie ma miejsca na państwa terytorialne?

„Utopia będzie zaspokajała moje potrzeby, a ja wszystkie swe siły poświęcę naszemu wspólnemu wysiłkowi, wytyczającemu ludzką ścieżkę od śmierci ku gwiazdom" (Palmer 2020, 401) - deklarują Utopianie, wstępując do Pasieki. Godło Utopii ukazuje trzy schematyczne globy (Ziemię, Księżyc i Marsa) i oddalające się od niebieskiej planety rakiety, a stolica Pasieki mieści się na Księżycu. Najważniejszym przedsięwzięciem Pasieki jest boleśnie powolna i mająca trwać jeszcze przez wiele pokoleń terraformacja Marsa, a większość Utopian nigdy nie zobaczy efektów swoich wysiłków. Ziemi opisywanej przez Palmer nie grożą katastrofa klimatyczna ani wyczerpanie zasobów naturalnych, powodujące współcześnie wzrost zainteresowania projektami snutymi przez na przykład Elona Muska. Rozpaczliwe pragnienie Utopii, by kolonizować kosmos, wydaje się niezrozumiałe - nie ma bowiem, przynajmniej w sytuacji wyjściowej cyklu, żadnych powodów, dla których ucieczka z Ziemi miałaby być konieczna. Poświęcanie przez setki lat zasobów na przekształcenie innej planety zamiast wykorzystywania ich na miejscu jawi się jako marnotrawstwo.

Utopianie uciekają z Ziemi, bo w tym, co wszyscy pozostali uznają za utopię, utopii nie widzą. W sytuacji, w której kontestowany porządek nie ma terytorium i ogarnia cały glob, pozostaje jedynie lokować niewypowiedziane wybawienie poza planetą: na Marsie, czyli nigdzie. Jednocześnie jednak, jak pokazuje trzeci tom cyklu Palmer, ta niewypowiedziana marsjańska utopia, choć ku niej Pasieka kieruje wszystkie swoje

W sytuacji, w której kontestowany porządek nie ma terytorium i ogarnia cały glob, pozostaje jedynie lokować niewypowiedziane wybawienie poza planetą: na Marsie, czyli nigdzie. 
- niespójne i nieprzynoszące widocznych od razu skutków - wysiłki, nie jest czymś, co sprawia, że Utopianie całkowicie tracą zainteresowanie życiem politycznym i społecznym. W obliczu nadciągającej i mającej ogarnąć cały glob wojny to Utopia wykonuje inicjalny krok, niszcząc lub zabezpieczając wszystko, co mogłoby stać się bronią masowego rażenia i doprowadzić do zagłady ludzkości. W czasie traktowanych jako ostatnia nadzieja na zachowanie pokoju igrzysk olimpijskich Utopia transmituje z Marsa pokaz sztucznych ogni - decydując się na ten czysto symboliczny gest ze świadomością, że na spalony w jego trakcie tlen pracowały pokolenia. To przeciw Utopii zwraca się też pierwsze uderzenie rozpoczynające wojnę.

Jeśli traktować obywateli Pasieki jako alegorię, należy zwrócić uwagę na kilka kwestii. Po pierwsze, możliwość jakiejkolwiek realnej zmiany jest w powieściach Palmer powiązana nie z reformami, a z całkowitą katastrofą znoszącą stary porządek (nadciągająca wojna) lub z porzuceniem starej rzeczywistości i stworzeniem innego świata od podstaw (terraformacja Marsa). Nawet jeśli ktoś dokona drugiego wyboru, cel jest tak odległy i zmitologizowany, że ma u Palmer charakter eschatologiczny. Po drugie, niemal wszyscy Utopianie zmuszeni są pozostać na rządzonej przez potężniejsze Pasieki Ziemi i pracować na niej nad ustanowieniem rzeczywistości, której sami nie doświadczą. Mało tego, odrzucenie (neo) liberalnego porządku nie sprawia, że możliwe jest funkcjonowanie poza nim - Utopia, choć ma słabą pozycję przetargową, angażuje się w spory polityczne i wciąż walczy o przetrwanie planety, którą przecież spisała na straty, całą nadzieję pokładając w Marsie. Apofatyczny utopianizm nie jest jednoznaczny ani z biernością, ani z byciem wyjętym spod władzy obecnej rzeczywistości. Po trzecie, i chyba najbardziej interesujące - Utopia, choć nie panuje w niej konsensus co do kształtu przyszłości i długodystansowych celów, na Ziemi działa w sposób zadziwiająco zgodny, mobilizując się natychmiastowo wobec rządzących światem potęg i koordynując wysiłki konstelacji tak, aby ratować szansę na zaistnienie jakiejkolwiek formy przyszłości.

Fisher paraliżującemu pesymizmowi realizmu kapitalistycznego przeciwstawiał - nie w pełni wyłożoną i odtwarzaną przez lewicę z niedokończonych pism teoretyka - kontrkulturową koncepcję komunizmu kwasowego, który opierać się miał nie tylko na wspólnotowości, ale przede wszystkim na umożliwieniu podmiotom przekroczenia ich historycznych czy socjoekonomicznych uwarunkowań ku czemuś nowemu (Fisher 2018). Kwasowość polegałaby (między innymi) na poszerzeniu wyobraźni i zdolności przywoływania - czy powoływania - obrazów świata bez kapitalizmu, całkowicie odmiennego i niemożliwego do 
wyobrażenia sobie w realizmie kapitalistycznym. Kwasowość mogłaby pozwolić odzyskać czy też wynaleźć na nowo przyszłość i wyrwać się z trwającego od kilkudziesięciu lat „teraz”. Być może w kategoriach kwasowości należałoby opisywać działania Utopian, odmawiających zaakceptowania trwającej od wieków i niezmieniającej się teraźniejszości, poświęcających życie wynajdywaniu kolejnych wersji przyszłości i chcących wręcz fizycznie wyrwać się ku temu, co nieznane. Przywiązanie Pasieki do dwudziestowiecznego imaginarium fantastyki i ciągłe przetwarzanie najbardziej ogranych motywów dawnej popkultury podważałoby jednak taką interpretację. Utopia, choć chce zakończyć neoliberalny paraliż czasu i dąży do przyszłości, nie umie zaprezentować jej w kategoriach radykalnej nowości. Brakuje jej do tego języka i jedyne, czym dysponuje to mit - czyli znane i nam imaginarium fantastycznonaukowe z czasów poprzedzających nastanie realizmu kapitalistycznego. Mało tego, to właśnie wspólny język odniesień, motywów czy imion nowych świętych - a więc tego, co nienowe - może stanowić czynnik wspólnototwórczy. Marksizm apofatyczny, nawet w wydaniu kosmicznym, należałoby zatem traktować jako zjawisko od komunizmu kwasowego odmienne. Nie wymaga ono od naszej uwarunkowanej i historycznej wyobraźni przekroczenia granic tego, co wyobrażalne - ale wciąż zachowuje potencjał krytyczny. Nawet oddanie Ziemi we władanie realizmu kapitalistycznego nie musi oznaczać całkowitego złożenia broni, jak długo poza Ziemią istnieją inne, niemożliwe jeszcze do opisania światy.

\section{Wykaz literatury}

Badiou, Alain. 2001. „On Evil.” Wywiad przeprowadzony przez Cristopha Coxa i Molly Whalen. Cabinet, Winter 2001-2002. https:// www.cabinetmagazine.org/issues/5/cox_whalen_badiou.php.

Canavan, Gerry. 2018. Worlding Crisis, Crisising Worlds, wykład wygłoszony w trakcie konferencji Worlding SF na Uniwersytecie Karola i Franciszka w Grazu.

Esposito, Roberto. 2015. „Immunizacja i przemoc.” Tłum. Magdalena Wrana. W Pojęcia polityczne. Wspólnota, immunizacja, biopolityka. Wstęp Mateusz Burzyk. Tłum. zbiorowe. Kraków: Universitas.

Fisher, Mark. 2018. „Part Seven. Acid Communism.” W K-Punk: The Collected and Unpublished Writings of Mark Fisher, red. Darren Ambrose. Wstęp Simon Reynolds. London: Repeater. EPUB. 2020. Realizm kapitalistyczny. Czy nie ma alternatywy? Tłum. 
Anna Karalus. Warszawa: Książka i Prasa.

Frase, Peter. 2018. Cztery przyszłości. Wizje świata po kapitalizmie. Tłum. Maciej Szlinder. Warszawa: Wydawnictwo Naukowe PWN. Freedman, Carl. 2009. „Dialectics of Science Fiction and Film Noir.” W Red Planets: Marxism and Science Fiction, red. Mark Bould i China Miéville. Middletown: Pluto Press.

Geoghegan, Vincent. 2008. Utopianism and Marxism. Bern: Peter Lang. Jameson, Fredric. 2011a. Archeologie przysztości. Pragnienie zwane utopia i inne fantazje naukowe. Tłum. Maciej Płaza, Małgorzata Frankiewicz i Andrzej Miszk. Kraków: Wydawnictwo Uniwersytetu Jagiellońskiego. —. 2011b. Postmodernizm, czyli logika kulturowa późnego kapitalizmu. Tłum. Maciej Płaza. Kraków: Wydawnictwo Uniwersytetu Jagiellońskiego.

Foucault, Michel. 2000. „Czym jest Oświecenie?” W Filozofia, historia, polityka. Wybór pism. Tłum. Damian Leszczyński i Lotar Rasiński. Warszawa-Wrocław: Wydawnictwo Naukowe PWN.

Levitas, Ruth. 2013. Utopia as Method: The Imaginary Reconstitution of Society. Basingstoke: Palgrave Macmillan.

Miéville, China. 2019. „Silence In Debris: Towards an Apophatic Marxism." Salvage, April 2, https://salvage.zone/in-print/silence-in-debris-towards-an-apophatic-marxism/.

Moylan, Thomas. 1986. Demand the Impossible: Science Fiction and the Utopian Imagination. London: Methuen.

- 2000. Scraps of the Untainted Sky: Science Fiction, Utopia, Dystopia. Boulder-Oxford: Westview Press.

Otto, Rudolf. 1999. Świętość: elementy irracjonalne w pojęciu bóstwa i ich stosunek do elementów racjonalnych. Tłum. Bogdan Kupis. Warszawa: Wydawnictwo KR.

Palmer, Ada. 2019a. Siedem kapitulacji. Tłum. Michał Jakuszewski. Warszawa: MAG.

—. 2019b. Do błyskawicy podobne. Tłum. Michał Jakuszewski. Warszawa: MAG.

—. 2020. Zdecydowani na walkę. Tłum. Michał Jakuszewski. Warszawa: MAG.

Ryan, Marie-Laure. 2012. „Narration in Various Media.” The Living Handbook of Narratology, January 13, https://www.lhn.uni-hamburg. de/node/53.html.

Suvin, Darko. (1979) 2016. Metamorphoses of Science Fiction: On the Poetics and History of a Literary Genre. red. Gerry Canavan. Bern: Peter Lang.

. 1988. Positions and Presuppositions in Science Fiction. London: Palgrave Macmillan. 
AGNIESZKA URBAŃCZYK - kulturoznawczyni i literaturoznawczyni, doktorantka na Wydziale Polonistyki UJ. Zajmuje się przede wszystkim kulturą fanowską i politycznością kultury popularnej, a w szczególności science fiction. Publikowała między innymi w „Tekstach Drugich” i „Przestrzeniach Teorii”, jest także jedną z autorek tekstów do mającego się ukazać The Routledge Handbook to Star Trek. Jej monografia Utopia jest sprzedawana oddzielnie. Polityczność science fiction $w$ recepcji fanowskiej (na przykładzie „Star Treka”) zostanie wydana pod koniec 2021 roku w Księgarni Akademickiej.

\section{Dane adresowe:}

Wydział Polonistyki Uniwersytetu Jagiellońskiego

ul. Gołębia 16

31-007 Kraków

email: agnieszka.urbanczyk@op.pl

\section{Cytowanie:}

Urbańczyk, Agnieszka. 2021. „Terra Ignota. Marksizm kosmiczny jako marksizm apofatyczny." Praktyka Teoretyczna 41(3): 91-111.

DOI: $10.14746 /$ prt.2021.3.5

Author: Agnieszka Urbańczyk

Title: Terra Ignota. Cosmic Marxism as an Apophatic Marxism

Summary: The article discusses Ada Palmer's Terra Ignota series, which problematizes the liberal nature of contemporary utopias. The fictional 25th century, in which gender, nation states and the traditional understanding of the family-but not inequalities-have been abolished, is contrasted with the ideals a small percentage of the population. While the fictional reality is treated as a utopia by the majority of characters, the Utopians strive for a radical rupture from the contingency and pledge themselves to the unknown future. Since the states in Palmer's world lack territory and it is impossible for Utopia to form an enclave on Earth, the Hive dedicates itself to terraforming Mars, with leaving Earth as their one common goal. The tasks the Utopians undertake are not rooted in a coherent homogenous project but seem to be grounded in a protest against the status quo naturalized by the rest of society. The Utopian strategy is treated as an example of China Miéville's apophatic Marxism. Apophasis remains a powerful tool of critique and an incentive to take action

Keywords: utopia, apophatic Marxism, Terra Ignota, Ada Palmer, science fiction 